\title{
Otolith elemental evidence for spatial structuring in a temperate reef fish population
}

\author{
Nicola A. Beer ${ }^{1, *}$, Stephen R. Wing ${ }^{1}$, Stephen E. Swearer ${ }^{2}$ \\ ${ }^{1}$ Department of Marine Science, University of Otago, Dunedin 9054, New Zealand \\ ${ }^{2}$ Department of Zoology, University of Melbourne, Victoria 3010, Australia
}

\begin{abstract}
Elemental fingerprints of calcified structures can provide useful insight into dispersal, structure and connectivity of fish and invertebrate populations, but an assumption must be made that fingerprints reflect local physico-chemical conditions at the time of accretion. Physiological control of elemental uptake and temporal variability in environmental conditions can confound interpretation of spatial patterns. Multiple lines of evidence suggest that a commercially important temperate reef fish Parapercis colias (Forster 1801) (Pinguipedidae) in the New Zealand fjords forms discrete subpopulations at the mesoscale (10 to $20 \mathrm{~km}$ ). We investigate otolith microchemistry as a tool to elucidate population structure and connectivity in the southern fjords. Concentrations of 12 elements ( $\mathrm{Li}, \mathrm{B}, \mathrm{Mg}, \mathrm{P}, \mathrm{S}, \mathrm{Ca}, \mathrm{Mn}, \mathrm{Cu}, \mathrm{Zn}, \mathrm{Sr}, \mathrm{Ba}$ and $\mathrm{Pb}$ ) were measured at the otolith edge (the most recently accreted region) using laser ablation inductively coupled plasma mass spectrometry (ICP-MS). Demographic and temporal variability were accounted for before spatial patterns were investigated. $\mathrm{P}: \mathrm{Ca}, \mathrm{Sr}: \mathrm{Ca}$ and $\mathrm{Ba}: \mathrm{Ca}$ ratios were positively correlated while $\mathrm{Li}$ :Ca was negatively correlated with age. Inter-annual variability in signatures within a single site was widespread. Independent of demography, fingerprints differed between inner and outer fjord subpopulations in Bradshaw-Thompson, Breaksea and Dusky Sounds but not in Doubtful Sound or Long Sound-Preservation Inlet. Solution and laser ablation ICP-MS were similarly able to discriminate between subpopulations of fish in a subset for which one sagitta was analysed by each technique. The assumption that fingerprints represent environmental conditions at the time of accretion is supported by a relocation study between habitats in Doubtful Sound. These results have important implications for temperate reef fish management and support the adoption of spatially explicit measures such as those in place in the New Zealand fjords.
\end{abstract}

KEY WORDS: Population connectivity · Otolith microchemistry · ICP-MS · Trace element analysis · Fiordland $\cdot$ Blue $\operatorname{cod} \cdot$ Parapercis colias

Resale or republication not permitted without written consent of the publisher

\section{INTRODUCTION}

The microchemical composition of calcified structures in marine vertebrates and invertebrates can provide useful insights into stock structure (Thresher 1999), larval dispersal (Thorrold et al. 2002) and connectivity between habitats associated with ontogenetic (Secor 1992, Gillanders et al. 2003) and adult movements (Campana et al. 2007). Trace, minor and major elemental concentrations have been recorded in teleost otoliths, scales, fin spines and eye lenses
(Gillanders 2001), but due to their biochronological properties, otoliths have proved the most useful structures for detecting geographic origin or change (Campana 1999). Determining population structure from otolith elemental fingerprints assumes that material is metabolically inert (Campana \& Neilson 1985) and that elements are incorporated in such a way as to reflect the physico-chemical environment at the time of accretion (Fowler et al. 1995, Gallahar \& Kingsford 1996), albeit with a degree of physiological regulation (Kalish 1989, Campana \& Thorrold 
2001). Ions are incorporated into the aragonitic otolith matrix or bound to the protein phase from the surrounding endolymph, and must pass across a branchial or intestinal cellular boundary (Campana 1999). In continuously drinking marine fishes, ions are sourced primarily from the water, with smaller branchial and dietary inputs (Campana 1999, Milton \& Chenery 2001). Whilst it is not always necessary to understand the physiological mechanisms underlying variability in otolith elemental fingerprints, consideration should be given to ionic sources and uptake pathways to prevent the age and size structure of the sampled population from confounding spatial patterns (Campana 1999). Physiologically regulated elements (e.g. $\mathrm{Mg}, \mathrm{P}, \mathrm{S}, \mathrm{Cu}, \mathrm{Zn}$ and $\mathrm{Pb}$ ) may be maintained at constant levels in otoliths despite considerable ambient variability, but can still act as useful markers provided concentrations vary among populations (Campana et al. 2000). Other elements such as $\mathrm{Li}, \mathrm{Sr}$ and $\mathrm{Ba}$ are likely to reflect physico-chemical conditions (Elsdon \& Gillanders 2003, Hicks et al. 2010), although the Sr:Ca ratio may also be related to growth rate (Sadovy \& Severin 1992, 1994). Mn is consistently elevated in otolith cores (Brophy et al. 2004, Ruttenberg et al. 2005), suggesting that in the natal and larval life history stages the Mn:Ca ratio is not related to environmental conditions or ambient concentrations (Bath et al. 2000, Elsdon \& Gillanders 2003, Miller 2009) but may be influenced by diet (Pentreath 1976, Mugiya et al. 1991, Sanchez-Jerez et al. 2002). However, in juvenile otoliths, Mn:Ca ratios may be affected by sediment type (Fodrie \& Herzka 2008) and by temperature in adults (S. E. Swearer unpubl. data).

Inter-annual differences in temperature, salinity and water chemistry mean that a population's elemental fingerprint may be temporally variable (Gillanders \& Kingsford 2000, Elsdon et al. 2008). This can complicate investigations of spatial structure or movement patterns. Otolith elemental concentrations are commonly measured using solution-based or laser ablation (LA) inductively coupled plasma mass spectrometry (ICP-MS). Solution-based ICP-MS measures bulk element concentrations in the whole otolith, integrated over the entire life history of an organism, and thereby avoids concerns over withinotolith heterogeneity (Sanborn \& Telmer 2003, Ludsin et al. 2006). LA ICP-MS on the other hand can target discrete portions of otolith growth; combined with the optical characteristics of the otolith, this ability to record chronologically explicit microchemical information allows a detailed record of a fish's environmental and physiological history to be reconstructed.
Temperate reef fish typically form spatially structured metapopulations at the mesoscale (10s to 100s m), with limited larval dispersal and adult mixing among subpopulations (Gunderson \& Vetter 2006). In the New Zealand fjords, the commercially and recreationally important blue cod Parapercis colias (Forster 1801) (Pinguipedidae) forms discrete subpopulations at the scale of 10 to $20 \mathrm{~km}$, with a subsidy of outer fjord and open coast adults into the highly resident inner fjord populations evident from markrecapture (Carbines \& McKenzie 2004) and stable isotopic studies (Rodgers \& Wing 2008). Decoupling of vital rates between inner and outer fjord populations is linked to habitat quality and may render populations vulnerable to localized depletion, particularly in the less productive inner fjords (N. Beer \& S. Wing unpubl.). The spatially explicit management measures introduced under the Fiordland Marine Management Act (2005) exclude commercial fishing from inner fjord waters and limit recreational catches, in addition to providing a network of refugia in the form of 10 no-take marine reserves. To adequately protect Fiordland blue cod populations, however, these management measures must act at an ecologically meaningful spatial scale.

Here, we employ an orthogonal sampling design to investigate spatial structuring between blue cod populations at paired inner and outer fjord sites in the 5 southern fjords. Size, age and sex effects on elemental uptake and the inter-annual stability of fingerprints are quantified before spatial structuring among sampled subpopulations is examined on the basis of otolith microchemical differences. The relative discriminatory power of solution and LA ICP-MS is tested using a subset of individuals for which one otolith of the sagittal pair was analyzed using each technique. In addition, we use otoliths from blue cod relocated from the outer fjord to the inner fjord (Rodgers \& Wing 2008) to test the assumption that otolith elemental fingerprints of a wild population reflect local physico-chemical conditions.

\section{MATERIALS AND METHODS}

\section{Sample collection}

Blue cod were sampled using artificial lures at paired inner and outer fjord sites throughout the southern fjords in November 2004 (n = 95) and April 2009 ( $\mathrm{n}=95$ ) (Fig. 1). For the relocation study, 46 adult blue cod were caught in outer Doubtful Sound from May to June 2004, tagged with individually 


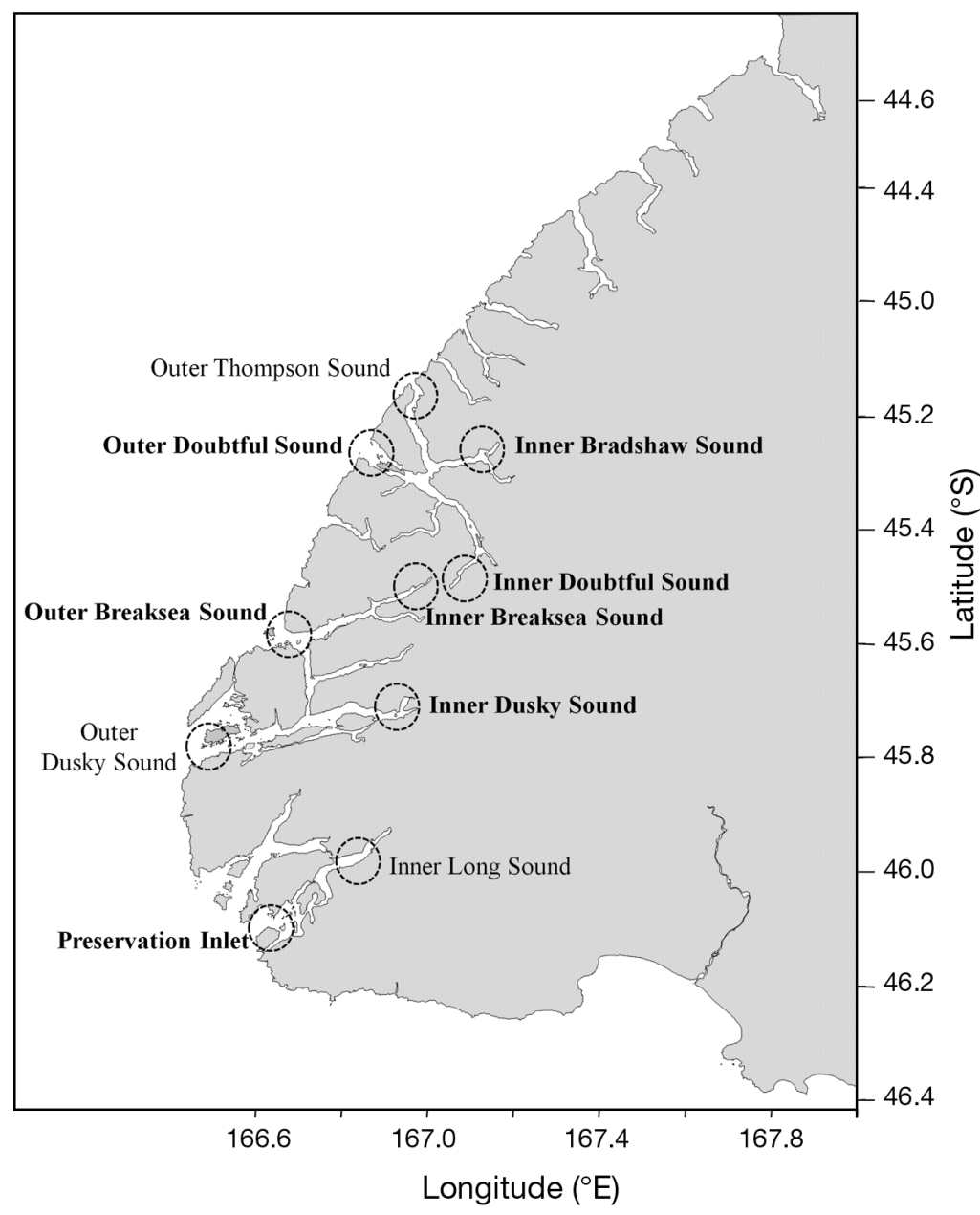

Fig. 1. Study sites in southern Fiordland, New Zealand. Not all sites were sampled in 2004; sites sampled in both 2004 and 2009 are in bold otolith pair was embedded in K142 epoxy resin (NUPLEX Construction Products). It is not expected that left and right otoliths of a pair would differ in their elemental composition (Campana et al. 1994), but for consistency and ease of sectioning, the right otolith was selected whenever possible. Transverse sections $(\sim 0.7 \mathrm{~mm}$ thick $)$ were cut through the primordium using a Buehler Isomet low-speed diamond-tipped saw and the sections mounted on glass slides using a small amount of resin. Age was estimated from sectioned otoliths prior to ICP-MS analysis.

\section{LA ICP-MS}

LA ICP-MS was carried out at the University of Melbourne's School of Earth Sciences using a Varian high sensitivity quadrupole ICP-MS fitted with a HelEx laser ablation system (Laurin Technic and Australian National University) constructed around a Compex 110 (Lambda Physik) Excimer laser. Preliminary analyses were conducted to determine the suite of elements that were consistently above detection limits and were not unduly subject to interference by polyatomic species (Table 2). The laser was operated at $60 \mathrm{~mJ}$ with a firing frequency of $5 \mathrm{~Hz}$. A $206 \mu \mathrm{m}$ diameter spot

numbered dart tags and released at Deep Cove in inner Doubtful Sound (Rodgers \& Wing 2008). Between June and November 2004, 6 tagged fish were recaptured in the vicinity of the release site after 15 to $184 \mathrm{~d}$ at liberty (Table 1 ). All fish were measured ( $\pm 1 \mathrm{~mm}$ total length [TL]) and sexed by macroscopic examination of the gonads. Although blue cod are protogynous hermaphrodites, sex inversion is a rapid process and terminal sex can be accurately determined macroscopically (Carbines 2004a,b). Sagittal otoliths were removed by cranial dissection, cleaned of adhering cerebral tissue in deionized water, transferred to sterile centrifuge tubes and left to air dry for several days. Otoliths were handled with Teflon-coated forceps only. Once fully dry, one of each
Table 1. Release and recapture date (dd.mm.yyyy), days at liberty, total length (TL), sex and age of tagged fish relocated from outer to inner Doubtful Sound

\begin{tabular}{|lcccccc|}
\hline Fish & Released & Recaptured & $\begin{array}{c}\text { Days at } \\
\text { liberty }\end{array}$ & $\begin{array}{c}\text { TL } \\
(\mathrm{mm})\end{array}$ & Sex & $\begin{array}{c}\text { Age } \\
(\mathrm{yr})\end{array}$ \\
\hline 1 & 25.05 .2004 & 09.06 .2004 & 15 & 339 & $\mathrm{M}$ & 7 \\
2 & 26.05 .2004 & 23.08 .2004 & 89 & 439 & $\mathrm{~F}$ & 8 \\
3 & 22.06 .2004 & 10.11 .2004 & 170 & 395 & $\mathrm{M}$ & 8 \\
4 & 22.06 .2004 & 11.11 .2004 & 171 & 386 & $\mathrm{M}$ & 6 \\
5 & 25.05 .2004 & 24.11 .2004 & 184 & 354 & $\mathrm{M}$ & 8 \\
6 & 25.05 .2004 & 24.11 .2004 & 184 & 375 & $\mathrm{M}$ & 8 \\
\hline
\end{tabular}


Table 2. Detection limits (DL) and instrument precision estimates (RSD) for suite of elements quantified using laser ablation (LA) inductively coupled plasma mass spectrometry (ICP-MS) in 2008 and 2009

\begin{tabular}{|lcccc|}
\hline Element & Isotope & Year & $\begin{array}{c}\text { DL }(\mu \mathrm{mol} \\
\left.\mathrm{mol}^{-1}\right)\end{array}$ & $\begin{array}{c}\text { RSD } \\
(\%)\end{array}$ \\
\hline $\mathrm{Li}$ & ${ }^{7} \mathrm{Li}$ & 2008 & 0.879 & 4 \\
& & 2009 & 4.614 & 4 \\
$\mathrm{~B}$ & ${ }^{11} \mathrm{~B}$ & 2008 & 2.200 & 6 \\
& & 2009 & 2.623 & 5 \\
$\mathrm{Mg}$ & ${ }^{24} \mathrm{Mg}$ & 2008 & 2.442 & 5 \\
& & 2009 & 1.316 & 3 \\
$\mathrm{P}$ & ${ }^{31} \mathrm{P}$ & 2008 & 16.201 & 5 \\
& & 2009 & 19.470 & 4 \\
$\mathrm{~S}$ & ${ }^{34} \mathrm{~S}$ & 2008 & 43.859 & 6 \\
& & 2009 & 54.272 & 7 \\
$\mathrm{Mn}$ & ${ }^{55} \mathrm{Mn}$ & 2008 & 0.473 & 3 \\
& & 2009 & 0.809 & 3 \\
$\mathrm{Cu}$ & ${ }^{63} \mathrm{Cu}$ & 2008 & 0.139 & 4 \\
& & 2009 & 0.436 & 4 \\
$\mathrm{Zn}$ & ${ }^{66} \mathrm{Zn}$ & 2008 & 0.204 & 5 \\
& & 2009 & 0.400 & 5 \\
$\mathrm{Sr}$ & ${ }^{88} \mathrm{Sr}$ & 2008 & 0.068 & 5 \\
& & 2009 & 0.302 & 4 \\
$\mathrm{Ba}$ & ${ }^{138} \mathrm{Ba}$ & 2008 & 0.002 & 4 \\
& & 2009 & 0.007 & 4 \\
$\mathrm{~Pb}$ & ${ }^{208} \mathrm{~Pb}$ & 2008 & 0.005 & 5 \\
& & 2009 & 0.008 & 4 \\
\hline
\end{tabular}

mise between temporal sensitivity and analytical detection power and represents $\sim 6$ to 12 mo of otolith growth. As elemental incorporation may be heterogeneous within an otolith (Hamer \& Jenkins 2007), all spots were positioned at the dorsal tip of the transverse section. Standards (NIST 610, NIST 612 and NIST 614) were analysed before and after blocks of 10 samples. Samples were analysed in a random order to avoid any potential instrument drift confounding examination of spatial variability in otolith elemental concentrations. Data were low-pass filtered off-line to remove transient spikes before being smoothed using a moving average of 3 cells, blanksubtracted and drift-corrected. The low-pass filter compared the cell value to the median of the target and 2 bracketing cells. For high background elements (all but $\mathrm{Ba}$ and $\mathrm{Pb}$ ), if the value was greater than twice the median, the cell value was replaced with the median value; for $\mathrm{Ba}$, the cell value was replaced if greater than $100+2 \times$ Median, and for $\mathrm{Pb}$, if greater than $150+2 \times$ Median. These threshold values were necessary to prevent filtering out high variation at low count rates during blank acquisition for low background elements. Elemental concentrations were then calculated from single-point calibrations using the NIST standard that most closely matched the concentration in the sample, and expressed as ratios relative to ${ }^{43} \mathrm{Ca}$ to correct for variable ablation yield. Detection limits were calculated for each element (3 SD above the mean blank for all sample and standard acquisitions) and expressed in molar ratios using the average ${ }^{43} \mathrm{Ca}$ count of the samples. External precision (relative standard deviation [RSD]) was based on replicate analyses (1 per block of 10 samples) of either NIST 612 (for elements calibrated using NIST 610) or NIST 614 (for elements calibrated using NIST 612) treated as an unknown.

Although individual scans sometimes fell below the selected instrumental detection limits, we chose to include these data as they can be useful in detecting spatial separation between sampled groups (Hicks et al. 2010, Fairclough et al. 2011), and we agree with Ben-Tzvi et al. (2007) that potentially interesting data may be unnecessarily discarded when they fall below arbitrarily determined thresholds. An average capture site signature was calculated from up to triplicate spots per sample following close examination of the raw data for each element; only 3 of these averaged replicates fell below the instrumental detection limits for the element $(0.14 \%$ of elemental averages). As the concentrations of certain metals $(\mathrm{Cu}, \mathrm{Zn}$ and $\mathrm{Pb})$ are particularly prone to surface or edge contamination, replicates (individual spots) were excluded from the individual average calculation if the concentration was $>3$ orders of magnitude greater than the mean. Photomicrographs of the ablated otolith sections were also examined to assess the quality of these sections; anomalously high concentrations were predominantly recorded in spots that were positioned too close to the edge of the otolith (i.e. touching the resin) or straddled a visible flaw in the section.

\section{Solution ICP-MS}

The remaining otolith from a subset of fish sampled in $2004(\mathrm{n}=55)$ was prepared for solution ICP-MS. Otoliths were washed for 8 to $10 \mathrm{~s}$ in $1 \% \mathrm{HNO}_{3}(65 \%$, Merck Suprapure $($ ), then rinsed 3 times in Milli-Q water, placed in labelled, acid-washed $10 \mathrm{ml}$ polypropylene centrifuge tubes and dried in a Class-100 laminar flow cabinet. Once dry, otoliths were weighed to the nearest $0.01 \mathrm{mg}$, dissolved in $1.5 \mathrm{ml}$ of $20 \% \mathrm{HNO}_{3}$ and made up to a final volume of $8 \mathrm{ml}$ with Milli-Q water. A subsample of this solution (0.5 or $1 \mathrm{ml}$, depending on otolith weight) was made up to $10 \mathrm{ml}$ with $1 \% \mathrm{HNO}_{3}$. A further $100 \times$ dilution was required to measure Sr. Procedural blanks were pre- 
pared in the same manner, but contained no otoliths. Solution ICP-MS was conducted at James Cook University's Advanced Analytical Centre using a Varian UltraMass 700 ICP-MS, calibrated using certified reference material NIES 22 (Fish Otolith Certified Reference Materials, Japan National Institute for Environmental Studies) and matrix-matched calibration solutions made of matrix otolith and a multi-element standard solution supplied by Choice Analytical. Concentrations were blank-subtracted and converted into ratios to $\mathrm{Ca}$, based on otolith dry wt and dilution factor. Detection limits (3 SD of the blanks; Gillanders \& Kingsford 2000) and instrument precision estimates (RSD, based on replicate measurements of a spiked otolith sample) are given in Table 3 .

\section{Statistical analysis}

Unless otherwise stated, statistical analyses were performed using PERMANOVA+ for PRIMER v6 (PRIMER-E), which calculates p-values under permutation and therefore avoids the assumptions of normality of distribution and homogeneity of variance inherent in traditional ANOVA tests. The effect of terminal sex (fixed effect), age and size (random effects) on 2009 capture site signatures was tested using permutational multivariate analysis of variance (MANOVA); where significant effects were detected, a permutation-based least squares linear model framework (DistLM) was used to correlate demographic factors with individual elemental concentrations. For those elements that were significantly correlated with demographic factors $(p<0.05)$, subsequent spatio-temporal comparisons used analysis of covariance (ANCOVA) with interactions included in the model to allow for heterogeneity of slopes (Quinn \& Keough 2002); non-significant interactions

Table 3. Detection limits (DL) and instrument precision estimates (RSD) for suite of elements quantified using solution inductively coupled plasma mass spectrometry (ICP-MS)

\begin{tabular}{|lccc|}
\hline Element & Isotope & $\begin{array}{c}\text { DL }(\mu \mathrm{mol} \\
\left.\mathrm{mol}^{-1}\right)\end{array}$ & $\begin{array}{c}\text { RSD } \\
(\%)\end{array}$ \\
\hline $\mathrm{Li}$ & ${ }^{7} \mathrm{Li}$ & $<0.001$ & 18 \\
$\mathrm{Mg}$ & ${ }^{24} \mathrm{Mg}$ & 0.018 & 7 \\
$\mathrm{Mn}$ & ${ }^{55} \mathrm{Mn}$ & 0.005 & - \\
$\mathrm{Cu}$ & ${ }^{63} \mathrm{Cu}$ & 0.002 & 10 \\
$\mathrm{Sr}$ & ${ }^{88} \mathrm{Sr}$ & 0.011 & 3 \\
$\mathrm{Ba}$ & ${ }^{138} \mathrm{Ba}$ & $<0.001$ & 5 \\
\hline
\end{tabular}

were pooled with residuals to increase model power. Capture site elemental signatures of blue cod sampled in 2009 were compared between fjords (fixed effect, 5 levels), habitats (fixed effect, 2 levels) and sites (fixed effect, 10 levels) using permutational MANOVA based on Euclidean distance between samples. Data were first normalized (mean $=0, \mathrm{SD}=$ 1) to account for inter-elemental differences in concentration ranges. Canonical analysis of principal coordinates (CAP) was used to measure reclassification-to-site success rates. Spatial trends in individual elements were examined using permutational ANOVA.

Capture site elemental signatures were compared between sampling years (random effect, 2 levels) using permutational MANOVA. As samples were analysed on 2 separate occasions (November 2004 samples were analysed in September 2008; April 2009 samples were analysed in October 2009), detection limits and machine precision estimates were compared between sampling events to ensure that analytical artefacts did not confound identification of temporal trends. Boron was excluded due to instrument calibration errors in 2008. CAP was used to compare reclassification success rates to year (pooled across sites) and to site (pooled across years). A separate CAP analysis used 2004 samples as a training dataset with which to assign 2009 samples to site.

Data from LA and solution ICP-MS analyses were compared using the subset of 2004 samples for which one otolith of the sagittal pair was analysed using each technique. The suite of elements was restricted to those measured by both techniques ( $\mathrm{Li}, \mathrm{Mg}, \mathrm{Mn}$, $\mathrm{Cu}, \mathrm{Sr}, \mathrm{Ba})$. Euclidean distance matrices of normalized data were compared using a Mantel test with 9999 permutations of the data in R v2.11.1 (The R Foundation for Statistical Computing), after Gillanders (2001).

Capture site signatures of relocated individuals were compared to signatures of fish of a similar age (6 to $8 \mathrm{yr}$ ) sampled from inner $(\mathrm{n}=15)$ and outer Doubtful Sound (n = 9) during November 2004. Group was treated as a fixed effect (3 levels). Distances of relocated signatures to multivariate inner and outer fjord group centroids were used to test the hypothesis that newly deposited otolith material will incorporate elements in concentrations reflecting local physico-chemical conditions and that consequently, over time, a relocated individual's otolith elemental signature will become progressively more similar to that of the local population and less similar to that of the population in its former habitat. 


\section{RESULTS}

\section{Demographic variability in otolith elemental fingerprints}

Blue cod sampled in 2009 ranged in age from 4 to $18 \mathrm{yr}$ and in size from 215 to $555 \mathrm{~mm}$. Elemental fingerprints did not vary with fish size or sex (nested within site, $p>0.05$ ) but did vary with age at sampling (nested within site, pseudo- $F_{47,94}=1.2985, \mathrm{p}=$ 0.0399). Age distributions differed between sites (pseudo- $F_{9,94}=9.4251, \mathrm{p}=0.0001$ ) and between all paired inner and outer fjord sites. Age was positively correlated with $\mathrm{P}: \mathrm{Ca}, \mathrm{Sr}: \mathrm{Ca}$ and $\mathrm{Ba}: \mathrm{Ca}$ ratios and negatively correlated with Li:Ca (Table 4).

\section{Spatial variability in otolith elemental fingerprints}

In 2009, spatial variability in multivariate fingerprints was evident at the fjord (pseudo- $F_{4,94}=2.4564$, $\mathrm{p}=0.0001$ ), habitat (pseudo- $F_{1,94}=2.1148, \mathrm{p}=$ 0.0449 ) and site level (pseudo- $F_{9,94}=2.7412, \mathrm{p}=$ 0.0001). Fingerprints differed among blue cod sampled in the 5 inner fjord basins (pseudo- $F_{4,45}=3.4632$, $\mathrm{p}=0.0001$ ) and among samples from the 5 outer fjord sites (pseudo- $F_{4,48}=2.1589, \mathrm{p}=0.0005$ ). Blue cod from inner and outer fjord habitats differed in their elemental fingerprints in Bradshaw-Thompson Sound (pseudo- $F_{1,19}=2.2672, \mathrm{p}=0.0234$ ), Breaksea Sound (pseudo- $F_{1,18}=3.7258, \mathrm{p}=0.0014$ ) and Dusky Sound (pseudo- $F_{1,20}=4.9650, \mathrm{p}=0.0001$ ) but not in Doubtful Sound (pseudo- $F_{1,14}=1.8621, \mathrm{p}=0.0866$ ) or Long Sound-Preservation Inlet (pseudo- $F_{1,19}=$ $0.7480, \mathrm{p}=0.5894)$. Reclassification-to-site success was $41 \%$ overall; 5.3 to $11.6 \%$ would be expected by

Table 4. Correlations between elemental concentrations in recently deposited otolith material and age-at-sampling. Significant correlations $(\mathrm{p}<0.05)$ are in bold

\begin{tabular}{|llrr|}
\hline Element & \multicolumn{1}{c}{ Equation } & $\mathrm{R}^{2}$ & $\mathrm{p}$ \\
\hline $\mathrm{Li}$ & $\mathrm{Li}=9.331-0.323$ (Age) & 0.06 & $\mathbf{0 . 0 1 9 2}$ \\
$\mathrm{B}$ & $\mathrm{B}=0.155-0.007$ (Age) & $<0.01$ & 0.7801 \\
$\mathrm{Mg}$ & $\mathrm{Mg}=0.116-0.002$ (Age) & 0.01 & 0.3194 \\
$\mathrm{P}$ & $\mathrm{P}=0.241+0.008$ (Age) & 0.07 & $\mathbf{0 . 0 1 0 8}$ \\
$\mathrm{S}$ & $\mathrm{S}=0.823-0.0004$ (Age) & $<0.01$ & 0.8890 \\
$\mathrm{Mn}$ & $\mathrm{Mn}=1.242-0.047$ (Age) & 0.04 & 0.0567 \\
$\mathrm{Cu}$ & $\mathrm{Cu}=0.662+0.035$ (Age) & $<0.01$ & 0.5894 \\
$\mathrm{Zn}$ & $\mathrm{Zn}=1.806-0.004$ (Age) & 0.02 & 0.1299 \\
$\mathrm{Sr}$ & $\mathrm{Sr}=2.590+0.082$ (Age) & 0.19 & $\mathbf{0 . 0 0 0 1}$ \\
$\mathrm{Ba}$ & $\mathrm{Ba}=1.491+0.146$ (Age) & 0.08 & $\mathbf{0 . 0 0 6 2}$ \\
$\mathrm{Pb}$ & $\mathrm{Pb}=0.037-0.0002$ (Age) & 0.02 & 0.1963 \\
& & & \\
\hline
\end{tabular}

chance according to sample size at each site. Within each fjord, reclassification to habitat was more successful with $>80 \%$ of samples correctly reclassified (chance: 33.3 to $66.7 \%$ ). Reclassification to fjord was more successful among inner (63\%) than outer (49\%) fjord samples. Spatial variability in individual elements was most evident at the site level (Table 5, Figs. 2 \& 3). B, Mg and Mn did not vary at any of the spatial scales modelled. Sr and Ba showed spatial variability independent of age distributions but $\mathrm{Li}$ and P did not.

Table 5. Permutational multivariate analysis of variance (PERMANOVA) tests comparing elemental concentrations between fjords, habitats and sites including test statistic pseudo- $F$, significance level $\mathrm{p}$ calculated under permutation, number of unique values obtained from 9999 permutations and df (factor, error). Age was included as a covariable in Li, $\mathrm{P}, \mathrm{Sr}$ and Ba models. Significant results $(\mathrm{p}<$ 0.05) are in bold

\begin{tabular}{|c|c|c|c|c|c|}
\hline Element & Test & $\begin{array}{c}\text { Pseudo- } \\
\text { F }\end{array}$ & $\mathrm{p}$ & $\begin{array}{l}\text { Unique } \\
\text { perms. }\end{array}$ & $\mathrm{df}$ \\
\hline $\mathrm{Li}$ & $\begin{array}{c}\text { Fjord } \\
\text { Habitat } \\
\text { Site }\end{array}$ & $\begin{array}{l}2.0081 \\
2.4581 \\
1.8479\end{array}$ & $\begin{array}{l}0.0867 \\
0.1198 \\
0.0624\end{array}$ & $\begin{array}{l}9944 \\
9847 \\
9954\end{array}$ & $\begin{array}{l}4,94 \\
1,94 \\
9,94\end{array}$ \\
\hline B & $\begin{array}{c}\text { Fjord } \\
\text { Habitat } \\
\text { Site }\end{array}$ & $\begin{array}{l}0.6211 \\
0.2036 \\
1.5014\end{array}$ & $\begin{array}{l}0.6520 \\
0.6478 \\
0.1505\end{array}$ & $\begin{array}{l}9956 \\
9928 \\
9949\end{array}$ & $\begin{array}{l}4,94 \\
1,94 \\
9,94\end{array}$ \\
\hline $\mathrm{Mg}$ & $\begin{array}{c}\text { Fjord } \\
\text { Habitat } \\
\text { Site }\end{array}$ & $\begin{array}{l}0.7792 \\
0.0802 \\
0.8957\end{array}$ & $\begin{array}{l}0.5428 \\
0.7690 \\
0.5326\end{array}$ & $\begin{array}{l}9944 \\
9859 \\
9957\end{array}$ & $\begin{array}{l}4,94 \\
1,94 \\
9,94\end{array}$ \\
\hline $\mathrm{P}$ & $\begin{array}{c}\text { Fjord } \\
\text { Habitat } \\
\text { Site }\end{array}$ & $\begin{array}{l}1.2623 \\
1.5002 \\
1.2484\end{array}$ & $\begin{array}{l}0.1627 \\
0.7672 \\
0.3823\end{array}$ & $\begin{array}{l}9961 \\
9862 \\
9948\end{array}$ & $\begin{array}{l}4,94 \\
1,94 \\
9,94\end{array}$ \\
\hline S & $\begin{array}{c}\text { Fjord } \\
\text { Habitat } \\
\text { Site }\end{array}$ & $\begin{array}{l}9.9721 \\
0.7178 \\
5.2984\end{array}$ & $\begin{array}{l}\mathbf{0 . 0 0 0 1} \\
0.4027 \\
\mathbf{0 . 0 0 0 2}\end{array}$ & $\begin{array}{l}9948 \\
9835 \\
9962\end{array}$ & $\begin{array}{l}4,94 \\
1,94 \\
9,94\end{array}$ \\
\hline Mn & $\begin{array}{c}\text { Fjord } \\
\text { Habitat } \\
\text { Site }\end{array}$ & $\begin{array}{l}1.1897 \\
0.4930 \\
1.4707\end{array}$ & $\begin{array}{l}0.3303 \\
0.4900 \\
0.1695\end{array}$ & $\begin{array}{l}9947 \\
9822 \\
9939\end{array}$ & $\begin{array}{l}4,94 \\
1,94 \\
9,94\end{array}$ \\
\hline $\mathrm{Cu}$ & $\begin{array}{c}\text { Fjord } \\
\text { Habitat } \\
\text { Site }\end{array}$ & $\begin{array}{l}2.2916 \\
0.5496 \\
2.6401\end{array}$ & $\begin{array}{l}0.0639 \\
0.4694 \\
\mathbf{0 . 0 0 9 2}\end{array}$ & $\begin{array}{l}9950 \\
9849 \\
9950\end{array}$ & $\begin{array}{l}4,94 \\
1,94 \\
9,94\end{array}$ \\
\hline $\mathrm{Zn}$ & $\begin{array}{c}\text { Fjord } \\
\text { Habitat } \\
\text { Site }\end{array}$ & $\begin{array}{l}1.0354 \\
2.0598 \\
4.1547\end{array}$ & $\begin{array}{l}0.2717 \\
\mathbf{0 . 0 4 6 6} \\
\mathbf{0 . 0 0 0 3}\end{array}$ & $\begin{array}{l}9942 \\
9818 \\
9948\end{array}$ & $\begin{array}{l}4,94 \\
1,94 \\
9,94\end{array}$ \\
\hline $\mathrm{Sr}$ & $\begin{array}{c}\text { Fjord } \\
\text { Habitat } \\
\text { Site }\end{array}$ & $\begin{array}{l}1.5967 \\
18.397 \\
4.1306\end{array}$ & $\begin{array}{l}0.1767 \\
\mathbf{0 . 0 0 0 3} \\
\mathbf{0 . 0 0 0 2}\end{array}$ & $\begin{array}{l}9946 \\
9842 \\
9950\end{array}$ & $\begin{array}{l}4,94 \\
1,94 \\
9,94\end{array}$ \\
\hline $\mathrm{Ba}$ & $\begin{array}{c}\text { Fjord } \\
\text { Habitat } \\
\text { Site }\end{array}$ & $\begin{array}{l}8.6474 \\
0.0580 \\
5.1582\end{array}$ & $\begin{array}{l}\mathbf{0 . 0 0 0 1} \\
0.0857 \\
\mathbf{0 . 0 0 0 1}\end{array}$ & $\begin{array}{l}9949 \\
9836 \\
9945\end{array}$ & $\begin{array}{l}4,94 \\
1,94 \\
9,94\end{array}$ \\
\hline $\mathrm{Pb}$ & $\begin{array}{c}\text { Fjord } \\
\text { Habitat } \\
\text { Site }\end{array}$ & $\begin{array}{l}2.9963 \\
3.8983 \\
5.3122\end{array}$ & $\begin{array}{l}0.0176 \\
0.0446 \\
0.0001\end{array}$ & $\begin{array}{l}9956 \\
9856 \\
9948\end{array}$ & $\begin{array}{l}4,94 \\
1,94 \\
9,94\end{array}$ \\
\hline
\end{tabular}



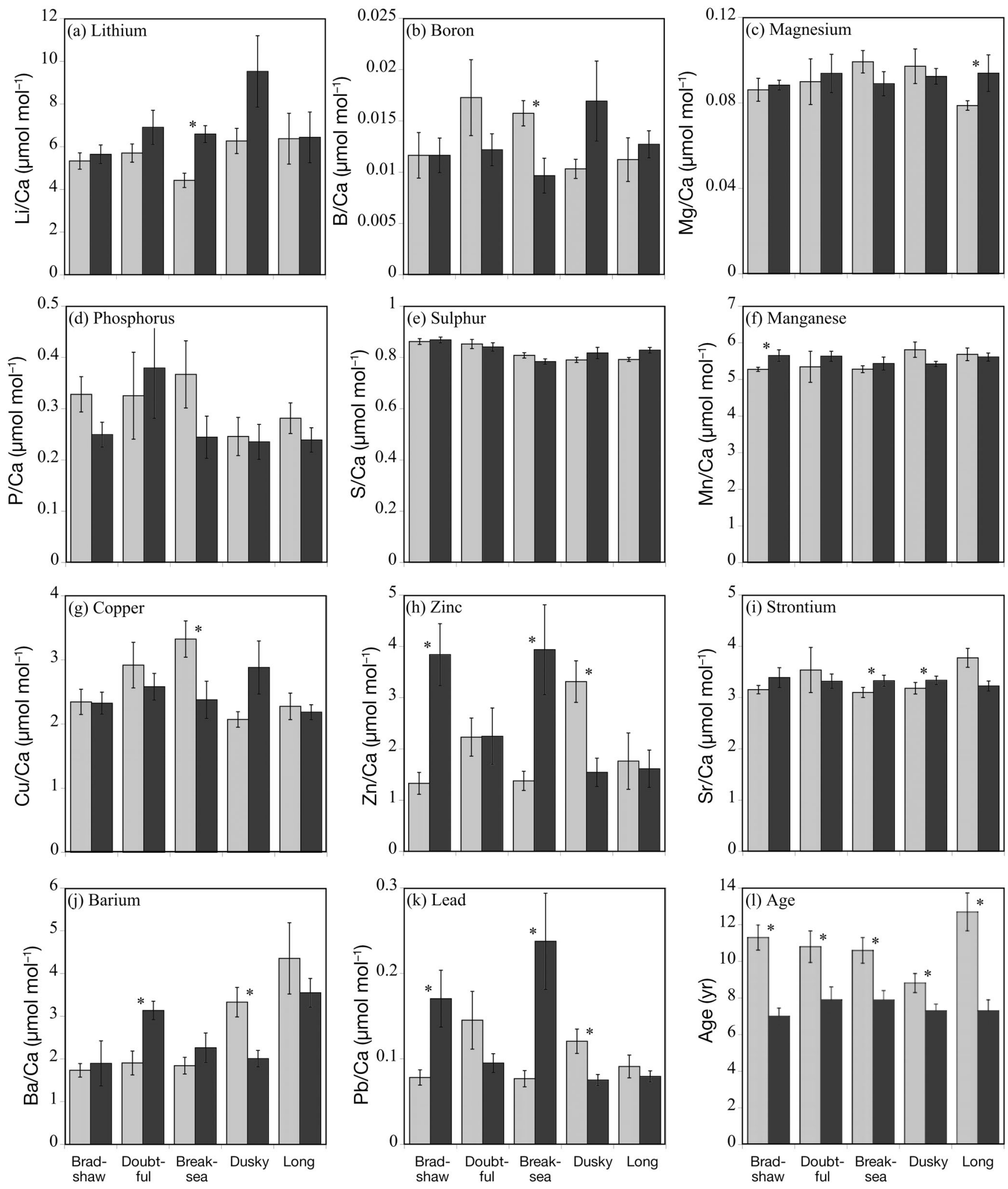

Fig. 2. Mean ( \pm SE) concentrations of (a) Li (b) B (c) Mg (d) P (e) S (f) Mn (g) Cu (h) Zn (i) Sr (j) Ba (k) Pb and (l) mean age at inner (grey bars) and outer (dark grey bars) fjord sites in each fjord in 2009. ${ }^{*}$ Significant difference $(p<0.05)$ between paired inner and outer fjord sites 


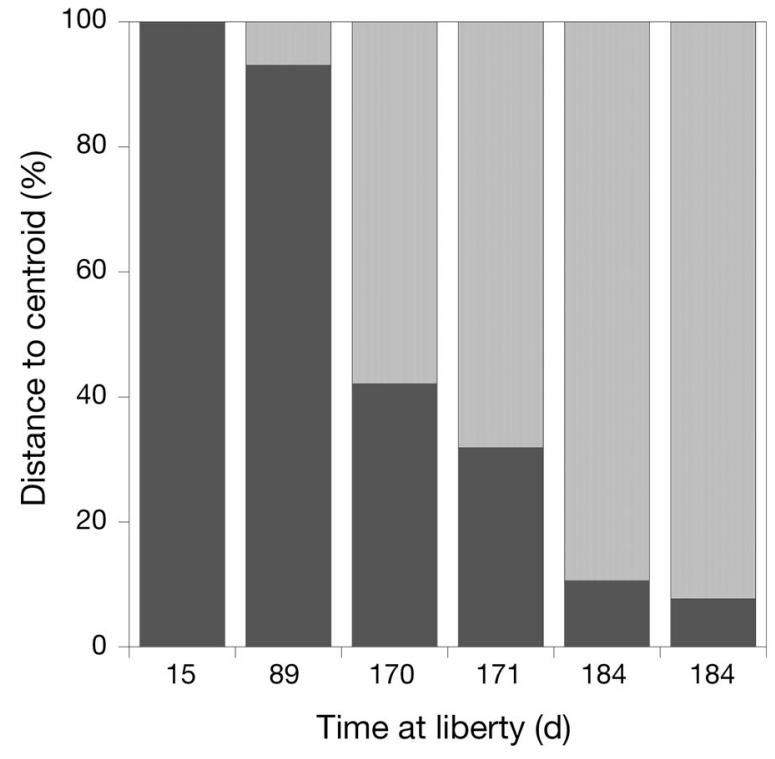

Fig. 3. Relative similarity of multivariate otolith elemental signatures of relocated fish to inner (light grey) and outer (dark grey) Doubtful Sound signatures after 15 to $184 \mathrm{~d}$ at liberty in the inner fjord

\section{Temporal variability in otolith elemental fingerprints}

Multivariate elemental fingerprints differed between blue cod sampled in 2004 and 2009 (nested within site: pseudo- $F_{6,139}=4.5142, \mathrm{p}=0.0001$ ), and at each site $>76 \%$ of samples could be correctly reclassified to sampling year. Temporal effects were detected in inner Bradshaw Sound (pseudo- $F_{1,19}=$ 2.0454, p = 0.0464), inner Doubtful Sound (pseudo$\left.F_{1,25}=2.2670, \mathrm{p}=0.0401\right)$, outer Breaksea Sound (pseudo- $\left.F_{1,19}=5.1595, \mathrm{p}=0.0001\right)$, inner Dusky Sound (pseudo- $F_{1,15}=5.5212, \mathrm{p}=0.0003$ ) and Preservation Inlet (pseudo- $F_{1,27}=6.2896, \mathrm{p}=0.0001$ ) but not outer Doubtful Sound (pseudo- $F_{1,29}=1.7796, \mathrm{p}=$ 0.0824). Of samples, $44 \%$ could be successfully reclassified to site and year overall (3.6 to $15.0 \%$ would be expected by chance alone). Reclassification to sampling year (pooled across sites: $79 \%$ ) was more successful than reclassification to sampling site (pooled across years: 48\%); however, 39.2 to $60.7 \%$ of samples could have been correctly reclassified to year by chance alone while just 11.4 to $21.4 \%$ could have been reclassified to site by chance. Using 2004 multivariate data as a training dataset by which to classify 2009 samples to site resulted in low success rates (16.4\% overall). Concentrations of $\mathrm{Mg}, \mathrm{S}, \mathrm{Cu}$, $\mathrm{Zn}, \mathrm{Sr}, \mathrm{Ba}$ and $\mathrm{Pb}$ differed between sampling years, nested within site $(\mathrm{p}<0.05)$, but Li, $\mathrm{P}$ and $\mathrm{Mn}$ did not $(\mathrm{p}>0.05)$.

\section{Comparison of LA and solution ICP-MS}

Successful reclassification to capture site included $47 \%$ of LA samples and $44 \%$ of solution samples (chance: 10.9 to $29.1 \%$ ). Under both techniques, 19 individuals $(34.5 \%)$ were misclassified, and 8 $(14.5 \%)$ of these were wrongly assigned to the same site. Sampling did not include all possible groups in the region so the direction of misclassifications is not discussed. Normalized Euclidean distance matrices for the 2 techniques were poorly correlated $(\mathrm{r}=$ -0.0048. $\mathrm{p}=0.4912$ ). Examination of the raw data revealed considerable variability in the relative concentrations of $\mathrm{Mg}, \mathrm{Mn}$ and $\mathrm{Cu}$ recorded at each site by both ICP-MS techniques. Age distributions were similar between sites and multivariate signatures did not vary with age for either technique ( $p>0.05)$, so it is unlikely that the difference in spatial patterns is related to the temporal sensitivity of each technique in terms of ontogeny. Relative concentrations of Li, $\mathrm{Sr}$ and $\mathrm{Ba}$ at each site were broadly similar between techniques; including just these 3 elements, normalized Euclidean distance matrices for the 2 techniques were significantly correlated $(r=0.1932, p=0.0292)$.

\section{Acclimatization to local physico-chemical conditions}

Otolith elemental fingerprints of blue cod relocated from outer to inner Doubtful Sound differed from those of the local inner fjord population (pseudo- $t=$ 1.6752, $\mathrm{p}=0.0271, \mathrm{df}=18$ ) but not from those of their native outer fjord population (pseudo- $t=0.9486, \mathrm{p}=$ 0.4635 , df $=12$ ). However, fingerprints of relocated fish after 170 to $184 \mathrm{~d}$ at liberty in the inner fjord could be distinguished from those of both inner fjord (pseudo- $t=2.4297, \mathrm{p}=0.0002, \mathrm{df}=16$ ) and outer fjord fish (pseudo- $t=1.6225, \mathrm{p}=0.0258, \mathrm{df}=10$ ). Over time, the elemental fingerprint of relocated fish became progressively more similar to an inner fjord signature and less similar to an outer fjord signature (Fig. 3). After just $15 \mathrm{~d}$ at liberty in the inner fjord, otolith microchemistry was typical of the fish's native outer fjord subpopulation; after $89 \mathrm{~d}$, an influence of the new inner fjord habitat was visible, and between 89 and $170 \mathrm{~d}$ this influence increased appreciably, but complete naturalization had not yet occurred after $184 \mathrm{~d}$.

\section{DISCUSSION}

Management of spatially structured populations must operate at an ecologically appropriate spatial 
scale in order to be effective. Consistent differences in otolith elemental fingerprints of Fiordland blue cod imply limited mixing between inner and outer fjord subpopulations over the scale of weeks to months, consistent with the results of mark-recapture and stable isotopic studies (Carbines \& McKenzie 2004, Rodgers \& Wing 2008). As reported for sea perch $\mathrm{He}$ licolenus percoides in the southern fjords (Lawton et al. 2010), blue cod elemental fingerprints were more discrete among inner fjord subpopulations, either as a result of isolation or distinct physico-chemical conditions in each fjord. Lower reclassification success rates among outer fjord subpopulations could reflect population mixing or the more dynamic environment in this exposed coastal habitat. The homogeneous fingerprints of blue cod sampled from inner and outer fjord habitats in Long Sound-Preservation Inlet is likely to reflect physico-chemical conditions in the relatively sheltered outer fjord environment, with its atypically estuarine ecosystem (Wing et al. 2003, Wing \& Jack 2010, N. Beer \& S. Wing unpubl.). Extensive mixing between inner and outer fjord subpopulations in this fjord is unlikely due to the strong spatial separation in population structure and growth rates (N. Beer \& S. Wing unpubl.).

An ontogenetic decrease in otolith Li:Ca ratio and an increase in P:Ca ratio has been observed in other species (Kalish et al. 1996, Begg et al. 1998, Stransky et al. 2005) but no mechanism has been suggested for either phenomenon. A positive correlation between otolith Sr:Ca ratio and age and has been attributed to changes in relative protein growth following maturation (Kalish 1989, Fuiman \& Hoff 1995, Friedland et al. 1998). We are unaware of any previous reports of a positive correlation between otolith $\mathrm{Ba}$ :Ca ratio and age for adult marine teleosts. The increase in blue cod Sr:Ca and Ba:Ca ratios with age may reflect an ontogenetic shift in habitat use (i.e. an environmental effect) or may be a physiological effect related to the kinetics of $\mathrm{Sr}^{2+}$ and $\mathrm{Ba}^{2+}$ incorporation into otolith material.

Interannual variability in blue cod otolith elemental fingerprints was considerable within a sampling location. As trophic ecology of subpopulations is consistent over a period of several years (N. Beer \& S. Wing unpubl.), the temporal variability in otolith microchemistry is unlikely to be driven by diet. Rather, it is likely to be due to complex variability in water chemistry at a range of temporal scales (Elsdon \& Gillanders 2006).

Spatial trends in $\mathrm{Li}: \mathrm{Ca}, \mathrm{Sr}: \mathrm{Ca}$ and $\mathrm{Ba}: \mathrm{Ca}$ ratios were well-correlated between solution and LA ICPMS analyses; previous comparative studies have reported similar results for $\mathrm{Sr}: \mathrm{Ca}$ and $\mathrm{Ba}: \mathrm{Ca}$ ratios (Thorrold et al. 1997, Ludsin et al. 2006), but no study to date has compared results for Li:Ca ratios between ICP-MS techniques. The similar discriminatory power of time-averaged and time-resolved techniques, despite the observed inter-annual variability in elemental signatures, likely reflects the highly resident nature of blue cod subpopulations in enclosed waterways (Cole et al. 2000, Carbines \& McKenzie 2004).

The results of our relocation study support the assumption that spatial variability in otolith microchemistry reflects the physico-chemical environment at the time of accretion. While we cannot determine the mechanism underlying the shift in elemental fingerprints following relocation, there is evidence to support both a dietary and a physico-chemical source. The same experimental fish displayed a transition in stable isotopic signatures after relocation, reflecting differences in the basal food web between habitats (Rodgers \& Wing 2008). Physico-chemical conditions in inner and outer Doubtful Sound are markedly different (Gibbs et al. 2000, Gibbs 2001) and mussels transplanted to cages in the inner, mid and outer fjord acquired discrete elemental fingerprints (Beer et al. 2011).

These results have important implications for the management of blue cod and other temperate reef fish populations that are spatially structured at the mesoscale. The tendency to form discrete subpopulations necessitates the adoption of management measures that act at a smaller, more ecologically meaningful spatial scale than is traditionally the case in fisheries management. Whilst it has long been recognised that invertebrate populations can be highly variable in their vital rates and productivity (Orensanz \& Jamieson 1998), there is evidence for a similar phenomenon among Fiordland blue cod subpopulations that is apparently related to differences in the food web between inner and outer fjord habitats (N. Beer \& S. Wing unpubl.). The persistence of discrete otolith elemental fingerprints over a period of several months and the spatial asynchrony in vital rates renders subpopulations vulnerable to localized depletion and necessitates spatially explicit management measures that are precautionary enough to allow for differential yields among adjacent populations.

Acknowledgements. We thank M. Beritzhoff, J. Davis, D. Ham, A. Hicks, K. Rodgers, B. Dickson, P. Heseltine and P. Meredith for their assistance with sample collection. Permission to collect samples from Gaer Arm (Kutu Parera) and Long Sound (Te Tapuwae O Hua) Marine Reserves was granted by the Department of Conservation and the Fiordland Marine 
Guardians. Monetary support was provided by the Commonwealth Scholarship and Fellowship Plan (NAB), a New Zealand Postgraduate Study Abroad Award (NAB) and a University of Otago Postgraduate Publishing Bursary (NAB).

\section{LITERATURE CITED}

Bath GE, Thorrold SR, Jones CM, Campana SE, McLaren JW, Lam JWH (2000) Strontium and barium uptake in aragonitic otoliths of marine fish. Geochim Cosmochim Acta 64:1705-1714

> Beer NA, Wing SR, Hu Y (2011) Physical versus biological control of element incorporation into biogenic carbonate: an in situ experiment in a New Zealand fjord. Mar Ecol Prog Ser 433:289-301

Begg GA, Cappo M, Cameron DS, Boyle S, Sellin MJ (1998) Stock discrimination of school mackerel, Scomberomorus queenslandicus, and spotted mackerel, Scomberomorus munroi, in coastal waters of eastern Australia by analysis of minor and trace elements in whole otoliths. Fish Bull 96:653-666

Ben-Tzvi O, Abelson A, Gaines SD, Sheehy MS, Paradis GL, Kiflawi M (2007) The inclusion of sub-detection limit LAICPMS data, in the analysis of otolith microchemistry, by use of a palindrome sequence analysis (PaSA). Limnol Oceanogr Methods 5:97-105

> Brophy D, Jeffries TE, Danilowicz BS (2004) Elevated manganese concentrations at the cores of clupeid otoliths: possible environmental, physiological, or structural origins. Mar Biol 144:779-786

- Campana SE (1999) Chemistry and composition of fish otoliths: pathways, mechanisms and applications. Mar Ecol Prog Ser 188:263-297

Campana SE, Neilson JD (1985) Microstructure of fish otoliths. Can J Fish Aquat Sci 42:1014-1032

- Campana SE, Thorrold SR (2001) Otoliths, increments, and elements: keys to a comprehensive understanding of fish populations? Can J Fish Aquat Sci 58:30-38

Campana SE, Fowler AJ, Jones CM (1994) Otolith elemental fingerprinting for stock identification of Atlantic cod (Gadus morhua) using laser ablation ICPMS. Can J Fish Aquat Sci 51:1942-1950

> Campana SE, Chouinard GA, Hanson JM, Fréchet A, Brattey J (2000) Otolith elemental fingerprints as biological tracers of fish stocks. Fish Res 46:343-357

> Campana SE, Valentin A, Sevigny DM, Power D (2007) Tracking seasonal migrations of redfish (Sebastes spp.) in and around the Gulf of St. Lawrence using otolith elemental fingerprints. Can J Fish Aquat Sci 64:6-18

Carbines G (2004a) Age determination, validation, and growth of blue cod Parapercis colias, in Foveaux Strait, New Zealand. NZ J Mar Freshw Res 38:201-214

Carbines G (2004b) Age, growth, movement and reproductive biology of blue cod (Parapercis colias: Pinguipedidiae): implications for fisheries management in the South Island of New Zealand. PhD thesis, University of Otago, Dunedin

Carbines G, McKenzie J (2004) Movement patterns and stock mixing of blue cod in Dusky Sound in 2002. New Zealand Fisheries Assessment Report 2004/36, Wellington

> Cole RG, Villouta E, Davidson RJ (2000) Direct evidence of limited dispersal of the reef fish Parapercis colias (Pinguipedidae) within a marine reserve and adjacent fished areas. Aquat Conserv Mar Freshw Ecosyst 10: 421-436
Elsdon TS, Gillanders BM (2003) Relationship between water and otolith elemental concentrations in juvenile black bream Acanthopagrus butcheri. Mar Ecol Prog Ser 260:263-272

> Elsdon TS, Gillanders BM (2006) Temporal variability in strontium, calcium, barium, and manganese in estuaries: implications for reconstructing environmental histories of fish from chemicals in calcified structures. Estuar Coast Shelf Sci 66:147-156

> Elsdon TS, Wells BK, Campana SE, Gillanders BM and others (2008) Otolith chemistry to describe movements and life-history parameters of fishes: hypotheses, assumptions, limitations and inferences. Oceanogr Mar Biol Annu Rev 46:297-330

> Fairclough DV, Edmonds JS, Lenanton RCJ, Jackson G, Keay IS, Crisafulli BM, Newman SJ (2011) Rapid and cost-effective assessment of connectivity among assemblages of Choerodon rubescens (Labridae), using laser ablation ICP-MS of sagittal otoliths. J Exp Mar Biol Ecol 403:46-53

Fodrie FJ, Herzka SZ (2008) Tracking juvenile fish movement and nursery contribution within arid coastal embayments via otolith microchemistry. Mar Ecol Prog Ser 361:253-265

Fowler AJ, Campana SE, Jones CM, Thorrold SR (1995) Experimental assessment of the effect of temperature and salinity on elemental composition of otoliths using solution-based ICPMS. Can J Fish Aquat Sci 52: 1421-1430

Friedland KD, Reddin DG, Shimizu N, Haas RE, Youngson AF (1998) Strontium:calcium ratios in Atlantic salmon (Salmo salar) otoliths and observations on growth and maturation. Can J Fish Aquat Sci 55:1158-1168

Fuiman LA, Hoff GR (1995) Natural variation in elemental composition of sagittae from red drum. J Fish Biol 47: 940-955

Gallahar NK, Kingsford MJ (1996) Factors influencing Sr/Ca ratios in otoliths of Girella elevata: an experimental investigation. J Fish Biol 48:174-186

Gibbs MT (2001) Aspects of the structure and variability of the low-salinity-layer in Doubtful Sound, a New Zealand fiord. NZ J Mar Freshw Res 35:59-72

Gibbs MT, Bowman MJ, Dietrich DE (2000) Maintenance of near-surface stratification in Doubtful Sound, a New Zealand fjord. Estuar Coast Shelf Sci 51:683-704

Gillanders BM (2001) Trace metals in four structures of fish and their use for estimates of stock structure. Fish Bull 99:410-419

Gillanders BM, Kingsford MJ (2000) Elemental fingerprints of otoliths of fish may distinguish estuarine 'nursery' habitats. Mar Ecol Prog Ser 201:273-286

Gillanders BM, Able KW, Brown JA, Eggleston DB, Sheridan PF (2003) Evidence of connectivity between juvenile and adult habitats for mobile marine fauna: an important component of nurseries. Mar Ecol Prog Ser 247:281-295

Gunderson DR, Vetter RD (2006) Temperate rocky reef fishes. In: Kritzer JP, Sale PF (eds) Marine metapopulations. Elsevier Academic Press, Amsterdam

> Hamer PA, Jenkins GP (2007) Comparison of spatial variation in otolith chemistry of two fish species and relationships with water chemistry and otolith growth. J Fish Biol 71:1035-1055

Hicks AS, Closs GP, Swearer SE (2010) Otolith microchemistry of two amphidromous galaxiids across an experi- 
mental salinity gradient: a multi-element approach for tracking diadromous migrations. J Exp Mar Biol Ecol 394:86-97

Kalish JM (1989) Otolith microchemistry: validation of the effects of physiology, age and environment on otolith composition. J Exp Mar Biol Ecol 132:151-178

Kalish JM, Livingston ME, Schofield KA (1996) Trace elements in the otoliths of New Zealand blue grenadier (Macruronus novaezelandiae) as an aid to stock discrimination. Mar Freshw Res 47:537-542

Lawton RJ, Wing SR, Lewis AM (2010) The New Zealand fjords contain discrete subpopulations of sea perch (Helicolenus percoides). NZ J Mar Freshw Res 44:309-322

Ludsin SA, Fryer BJ, Gagnon JE (2006) Comparison of solution-based versus laser ablation inductively coupled plasma mass spectrometry for analysis of larval fish otolith microelemental composition. Trans Am Fish Soc 135:218-231

Miller JA (2009) The effects of temperature and water concentration on the otolith incorporation of barium and manganese in black rockfish Sebastes melanops. J Fish Biol 75:39-60

Milton DA, Chenery SR (2001) Sources and uptake of trace metals in otoliths of juvenile barramundi (Lates calcarifer). J Exp Mar Biol Ecol 264:47-65

Mugiya H, Hakomori T, Hatsutori K (1991) Trace metal incorporation into otoliths and scales in the goldfish, Carassius auratus. Comp Biochem Physiol C 99:327-331

Orensanz JM, Jamieson GS (1998) The assessment and management of spatially structured stocks: an overview of the North Pacific Symposium on Invertebrate Stock Assessment and Management. In: Jamieson GS, Campbell A (eds) Proceedings of the North Pacific Symposium on Invertebrate Stock Assessment and Management. NRC Research Press, Nanaimo, p 441-459

Pentreath RJ (1976) Some further studies on the accumulation and retention of ${ }^{65} \mathrm{Zn}$ and ${ }^{55} \mathrm{Mn}$ by the plaice, Pleuronectes platessa L. J Exp Mar Biol Ecol 21:179-189

Quinn GP, Keough MJ (2002) Experimental design and data analysis for biologists. Cambridge University Press, Cambridge

Rodgers KL, Wing SR (2008) Spatial structure and movement of blue cod Parapercis colias in Doubtful Sound, New Zealand, inferred from $\delta^{13} \mathrm{C}$ and $\delta^{15} \mathrm{~N}$. Mar Ecol Prog Ser 359:239-248

Ruttenberg BI, Hamilton SL, Hickford MJH, Paradis GL and

Editorial responsibility: Stylianos Somarakis,

Heraklion, Greece others (2005) Elevated levels of trace elements in cores of otoliths and their potential for use as natural tags. Mar Ecol Prog Ser 297:273-281

Sadovy Y, Severin KP (1992) Trace elements in biogenic aragonite: correlation of body growth and strontium levels in the otoliths of the white grunt, Haemulon plumieri (Pisces, Haemulidae). Bull Mar Sci 50:237-257

Sadovy Y, Severin KP (1994) Elemental patterns in red hind (Epinephelus guttatus) otoliths from Bermuda and Puerto Rico reflect growth rate, not temperature. Can J Fish Aquat Sci 51:133-141

Sanborn M, Telmer K (2003) The spatial resolution of LAICP-MS line scans across heterogeneous materials such as fish otoliths and zoned minerals. J Anal At Spectrom 18:1231-1237

Sanchez-Jerez P, Gillanders BM, Kingsford MJ (2002) Spatial variability of trace elements in fish otoliths: comparison with dietary items and habitat constituents in seagrass meadows. J Fish Biol 61:801-821

Secor DH (1992) Application of otolith microchemistry analysis to investigate anadromy in Chesapeake Bay striped bass Morone saxatilis. Fish Bull 90:798-806

Stransky C, Garbe-Schönberg CD, Günther D (2005) Geographic variation and juvenile migration in Atlantic redfish inferred from otolith microchemistry. Mar Freshw Res 56:677-691

> Thorrold SR, Jones CM, Campana SE (1997) Response of otolith microchemistry to environmental variations experienced by larval and juvenile Atlantic croaker (Micropogonias undulatus). Limnol Oceanogr 42:102-111

Thorrold SR, Jones GP, Hellberg ME, Burton RS and others (2002) Quantifying larval retention and connectivity in marine populations with artificial and natural markers. Bull Mar Sci 70:291-308

> Thresher RE (1999) Elemental composition of otoliths as a stock delineator in fishes. Fish Res 43:165-204

Wing SR, Jack L (2010) Biological monitoring of the Fiordland (Te Moana o Atawhenua) Marine Area and Fiordland's Marine Reserves: 2010. Department of Conservation, Te Anau

Wing SR, Bowman MH, Smith F, Vennell R (2003) Analysis of biodiversity and management decision making processes to support stewardship of marine resources and biodiversity in Fiordland: a case study. Report 1 of 3 for the Ministry for the Environment, New Zealand. University of Otago, Dunedin

Submitted: June 1, 2011; Accepted: September 19, 2011

Proofs received from author(s): November 29, 2011 